\title{
Biofixation of Carbon dioxide by Chlamydomonas sp. in a Tubular Photobioreactor
}

\author{
Hadiyanto*, Sumarno, Rufaida Nur Rostika and Noer Abyor Handayani \\ Chemical Engineering Department, Faculty of Engineering, Diponegoro University, \\ Jl.Prof Sudharto,SH-Tembalang, Semarang INDONESIA
}

\section{Article history:}

Received December 19, 2011 Received in revised form Jan 12, 2012 Accepted January 23, 2012 Available online

\begin{abstract}
The biogas production from anaerobic digestion is a potential fuel for power generators application, if biogas can be upgraded to the same standards as fossil natural gas by $\mathrm{CO}_{2}$, $\mathrm{H}_{2} \mathrm{~S}$, and other non-combustible component removal. Microalgae Chlamydomonas sp. has potency to biofix the carbon dioxide and can be used as an additional food ingredient. The variations of flow rate and carbon dioxide concentration in the process resulting different value of biomass production and carbon dioxide biofixation. Biomass production at $40 \%$ carbon dioxide concentration obtained $5.685 \mathrm{gr} / \mathrm{dm}^{3}$ at $10 \%$ carbon dioxide concentration obtained $4.892 \mathrm{gr} / \mathrm{dm}^{3}$. The greatest value of carbon dioxide absorption occurs at a $40 \%$ concentration amounting to $12.09 \%$. The rate of growth and productivity of microalgae tend to rise in $10 \%$ and $20 \%$ (\%v) carbon dioxide concentration, but began started a constant at 30\% and $40 \%$ (\%v) carbon dioxide concentration. Biomass production tends to increase in light conditions while a constant in dark conditions. This study used Chlamydomonas $s p$. as media culture and performed on bubble column and tubular reactor with 6 litres of culture medium at a temperature of $28^{\circ} \mathrm{C}$ and atmospheric pressure.
\end{abstract}

Keywords: Microalgae, Chlamydomonas sp., Carbon dioxide biofixation, Biogas

\section{Introduction}

Crisis of energy has been considered as global issues. The increase of energy consumption due to increasing of population, number of industries, and lowering the fossil oil reserves have forced Indonesia to produce alternative energy such as biodiesel, biogas, and other biomass energy.

Biogas is a mixture of methane $\left(\mathrm{CH}_{4}\right)$, carbon dioxide $\left(\mathrm{CO}_{2}\right)$ and hydrogen sulphide $\left(\mathrm{H}_{2} \mathrm{~S}\right)$. The composition of biogas depends on the feedstock used, trace gases such as nitrogen $\left(\mathrm{N}_{2}\right)$, ammonia $\left(\mathrm{NH}_{3}\right)$, sulphur dioxide ( $\left.\mathrm{SO}\right)$, hydrogen sulphide $\left(\mathrm{H}_{2} \mathrm{~S}\right)$, and hydrogen $\left(\mathrm{H}_{2}\right)$ [1,2]. Biogas is produced when certain bacteria digest biological matter such as animal manure, organic wastes, fertilizer and biomass in an anaerobic environment. Anaerobic digestion is one of biological waste water treatment which has many advantages such as cleaner and healthier environment due to lower COD/BOD levels and produces methane as a renewable energy source [1]. Carbon dioxide $\left(\mathrm{CO}_{2}\right)$ and hydrogen sulphide $\left(\mathrm{H}_{2} \mathrm{~S}\right)$ are benefits compounds for biogas. However the used of $\mathrm{CO}_{2}$ and $\mathrm{H}_{2} \mathrm{~S}$ as biofuel due to $\mathrm{CO}_{2}$ reduces the caloric value and $\mathrm{H}_{2} \mathrm{~S}$ is corrosive component for vehicles. The caloric value of biogas which contains $30-40 \%$ carbon dioxide concentration is $4800-6900 \mathrm{kcal} / \mathrm{m}^{3}$ while the pure methane $\left(\mathrm{CH}_{4}\right)$ is $9000 \mathrm{kcal} / \mathrm{m}^{3}$ [2]. Therefore, $\mathrm{CO}_{2}$ and $\mathrm{H}_{2} \mathrm{~S}$ must be removed in order to be used as biofuel. The biogas production from anaerobic digestion is a potential fuel for power generators application, if biogas can be upgraded to the same standards as fossil natural gas by $\mathrm{CO}_{2}, \mathrm{H}_{2} \mathrm{~S}$, and other non-combustible component removal [2-4].

A biogas upgrading process can be applied to increase caloric value, minimize corrosion problems,

\footnotetext{
* Corresponding author. Tel: +62-24-7460058

E-mail:hadi.hadiyanto@gmail.com
} 
promote it to pseudo-natural gas quality and connect it to a pipeline for network distribution. There are several proper methods to reduce carbon dioxide emissions, such as physical, chemical and biological methods. Carbon dioxide biofixation through microalgae photosynthesis is one of biological methods. Carbon dioxide will be used as a carbon source of biomass through photosynthesis [11-14]. It was shown that microalgae have higher carbon dioxide fixation rates than terrestrial plants and can thus utilize carbon dioxide from flue gas to produce biomass [15-17]. Many applications have been shown by some authors for converting algae biomass to valuable products [1923]. In this study, we developed carbon dioxide biofixation using microalgae in tubular photobioreactor. In this system, we evaluated the growth of microalgae, Chlamydomonas sp., cultivated under variation of gas flow rate and different concentrations of carbon dioxide. The study was limited to carbon dioxide absorption while $\mathrm{H}_{2} \mathrm{~S}$ was not included in this study.

\section{Experimental Method}

\subsection{Microalgae Biofixation}

The wild-type microalgae Chlamydomonas sp. was obtained from Central of Biomass and Renewable Energy Laboratory, Chemical Engineering Department, Diponegoro University. The biofixation process of microalgae Chlamydomonas sp. is performed in a tubular photobioreactor under constant temperature of 28oC and atmospheric pressure. The flow rate of gas mixture $\left(\mathrm{CO}_{2}\right.$ and $\left.\mathrm{O}_{2}\right)$ was varied between $0.031 \mathrm{~L} / \mathrm{min}$ to $0.071 \mathrm{~L} / \mathrm{min}$, while carbon dioxide concentration was $10-40 \%$. The photobioreactor is continuously illuminated with a fluorescence lamp 60 Watt (Figure 1).

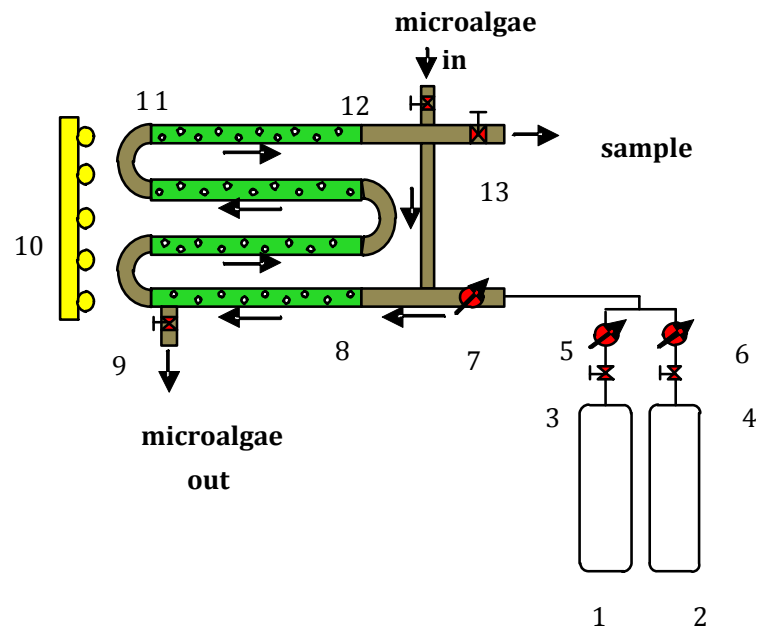

Fig. 1 A tubular photobioreactor for $\mathrm{CO}_{2}$ biofixation (1). $\mathrm{N}_{2}$ gas; (2). $\mathrm{CO}_{2}$ gas; (3). Gas valve for $\mathrm{N}_{2}$ gas; (4). Gas valve for $\mathrm{CO}_{2}$; (5). $\mathrm{N}_{2}$ flow meter (6). $\mathrm{CO}_{2}$ flowmeter (7). Flowmeter for microalgae; (8). tubular coloumn; (9). Effluent microalgae valve; (10). Lamp, (11). Elbow; (12) Valve inlet microalgae; (13) Sampling hole

\subsection{Measurement of microalgae cells and growth rates}

The biomass of microalgae was measured by the absorbance at $680 \mathrm{~nm}\left(\mathrm{~A}_{680}\right)$ in an Ultrospec 3300 pro UV/Visible spectrophotometer. Each sample was diluted to give an absorbance in the range of 0.1-1.0. Regression equations of the relationship between optical density and cell dry weight were shown as:

$\frac{\mathrm{CO}_{2} \text { was absorbed (mole) }}{\text { total } \mathrm{CO}_{2}} \times 100 \%$

Where $\mathrm{y}$ is biomass concentration $(\mathrm{g} / \mathrm{L})$ and the value $\mathrm{x}$ is optical density $\left(\mathrm{A}_{680}\right)$.

Pure culture of Chlamydomonas sp. was breeded in variations of concentration and gas flow rate of carbon dioxide. This breeding process aims to obtain microalgae growth rate data. Nutrient ratio was not set in the variation experiments of $10 \%$ and $20 \%(\% \mathrm{v})$ carbon dioxide concentration. However, nutrient ratio, which carbon as limiting factor, was used in variation experiments of $30 \%$ and $40 \%$ (\% v) carbon dioxide concentration.

The breeding process was terminated when the value of optical density closed to 1. Optical density analysis can be performed using a spectrophotometer at $680 \mathrm{~nm}$ wavelength $\left(\mathrm{OD}_{680}\right)$. Analysis of carbon dioxide which was absorbed by microalgae can be calculated using the following equation:

$$
\frac{\mu(t)}{d a y}=\ln \frac{x(t)}{x(o)}
$$

Analysis of biomass production was done by plotting the absorbance readings of each variable to a standard curve to be converted into biomass values.

Analysis of dark and light was carried out by cultivating the medium culture at a flow rate of 0.071 $\mathrm{L} / \mathrm{min}$ and $40 \%(\% \mathrm{v})$ carbon dioxide concentration. Variation of lighting was done every 6 hours, then analyzed the production of biomass.

Analysis of growth rate and biomass production can be calculated using the following equation:

$$
\frac{\text { productivity }}{\text { day }}=\frac{\text { biomass }}{\text { day }}
$$

Annotation:

$$
\begin{aligned}
& \mathrm{x}(\mathrm{t})=\text { biomass production at a certain time } \\
& \mathrm{x}(\mathrm{o})=\text { the initial biomass }
\end{aligned}
$$

Productivity values can be calculated by dividing the biomass production in particular concentration with cultivation time. In the variation of $10 \%$ and $20 \%(\% \mathrm{v})$ carbon dioxide concentration, the system adjusted to 
acidic $\mathrm{pH}$, while the variation of $30 \%$ and $40 \%(\% \mathrm{v})$ carbon dioxide concentration adjusted to alkaline $\mathrm{pH}$.

\section{Results and Discussion}

\subsection{Effect of carbon dioxide flow rate}

In this study, carbon dioxide flow rate be varied to determine the effects of carbon dioxide flow rate to the growth rate of microalgae, as shown in Figure 2.

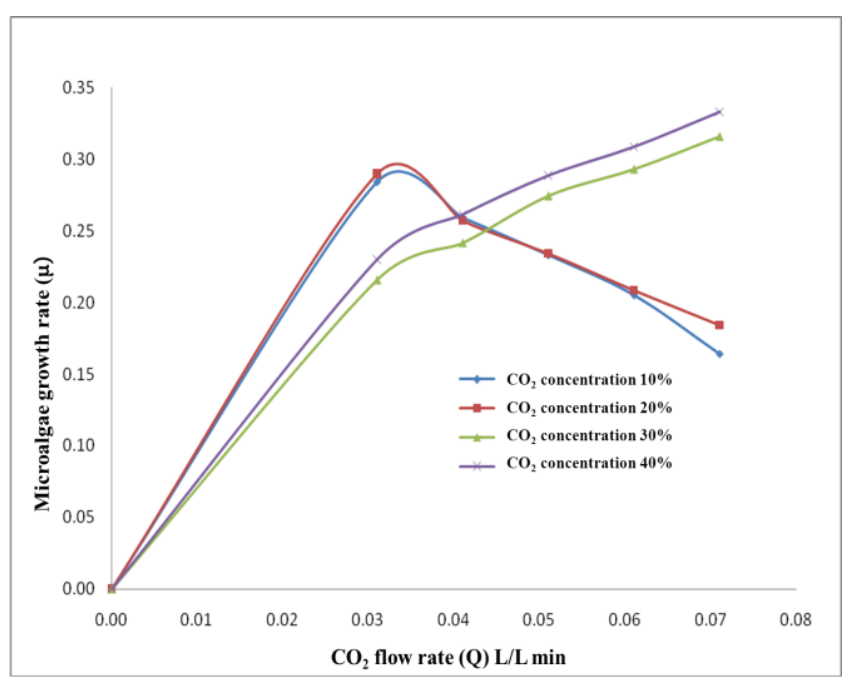

Fig. 2 Microalgae growth rate at various of carbon dioxide flow rate

In the study conducted Wilde and Benemann, it used buble column reactor with the variation of carbon dioxide ( $40 \%$ concentration) flow rate $0.1-0.5 \mathrm{~L} / \mathrm{min}$. They concluded that the higher carbon dioxide flow rate, so that the higher productivity and growth rate of microalgae [4]. However, this phenomenon was not seen at $10 \%$ and $20 \%(\% \quad v)$ carbon dioxide concentration. This research used opened design system so that it could cause the residence time of carbon dioxide in the culture medium was not optimal.

Thus, it was necessary to redesign the equipment so that carbon dioxide had longer residence time in the culture medium, and the growth rate of microalgae could be optimized. The equipment that has been redesign, as shown in Figure 2, used at 30\% and $40 \%$ $(\% \mathrm{v})$ carbon dioxide concentration.

\subsection{Effect of carbon dioxide concentration}

In this study, carbon dioxide concentration is varied to determine the effect of it on the biomass productivity, as shown in Figure 3.

Carbon dioxide is an important factor affecting the growth and metabolism of microalgae [5]. Microalgae have capability to absorb carbon dioxide in the range of $\mathrm{pH}$ and different carbon dioxide concentrations [6]. Figure 3 show that at the variation of $40 \%$ carbon dioxide concentration and flow rate $0.071 \mathrm{~L} / \mathrm{min}$, microalgae can produce biomass $5.685 \mathrm{gr} / \mathrm{dm}^{3}$. On the other side, of microalgae production only reached $4.892 \mathrm{gr} / \mathrm{dm}^{3}$ at $10 \%$ carbon dioxide concentration. The high concentrations of carbon dioxide (40\%) is absorbed by microalgae and used for photosynthesis processes. The photosynthesis takes place in the presence of sunlight and carbon dioxide to produce carbohydrates as the main source of biomass formation.

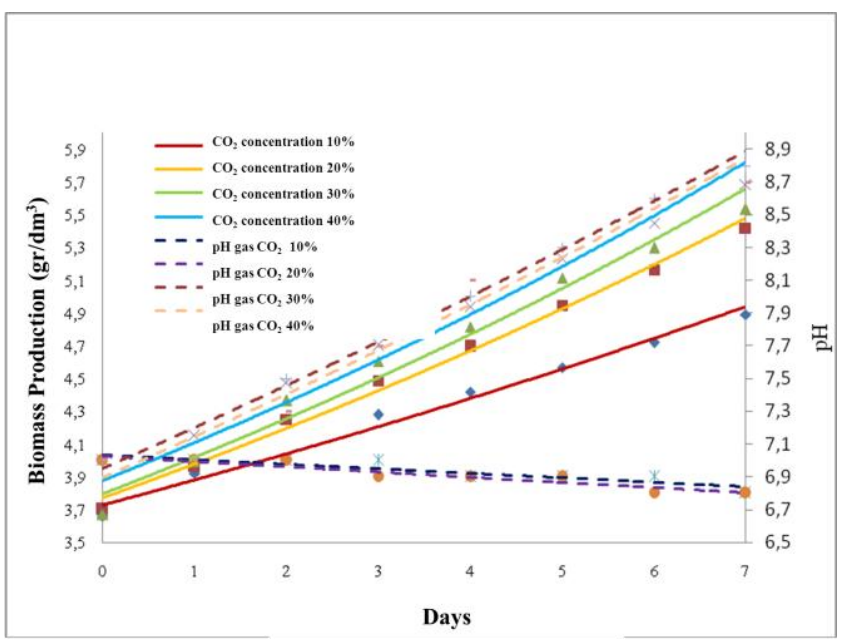

Fig. 3 Biomass production at various concentration of carbon dioxide $(\mathrm{Q}=0.071 \mathrm{~L} / \mathrm{min})$

\subsection{Effect of Growth Rate and Productivity}

In this study, growth rate of microalgae will be compared with the productivity in terms of carbon dioxide flow rate, as shown in Figure 4.

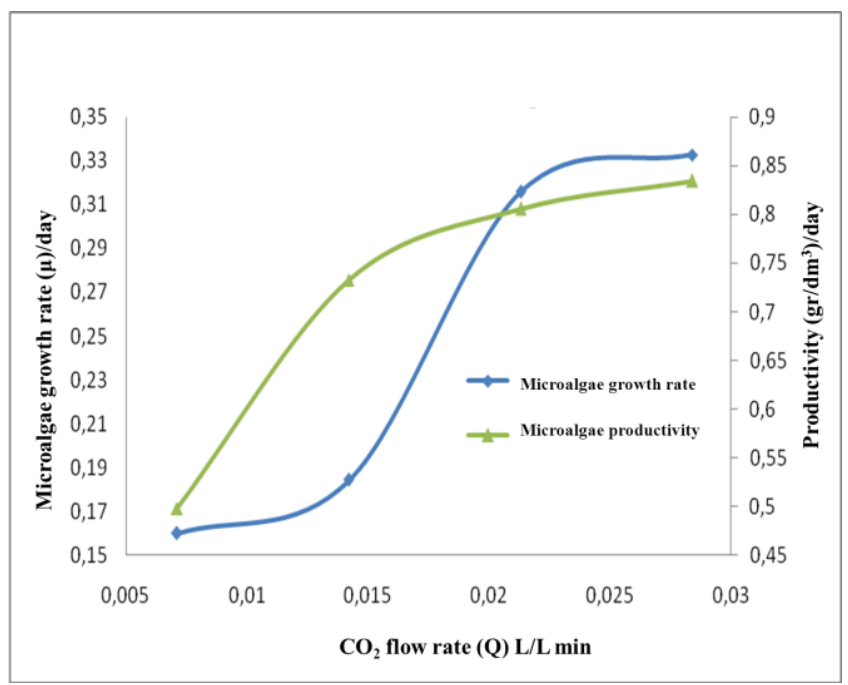

Fig. 4 Growth rate and productivity of microalgae

Growth rate of microalgae is directly proportional to biomass productivity due to the optimal growth rate will result in optimal productivity as well. Microalgae that have optimal growth will be more active to convert 
carbon dioxide into biomass, so that biomass productivity will be high [7].

Figure 4 shows that in the variation of $10 \%$ and $20 \%$ (\% v) carbon dioxide concentration, both growth rate and biomass productivity increases. Otherwise, in the variation of $30 \%$ and $40 \%$ ( $\%$ v) carbon dioxide concentration, either growth rate and biomass productivity begin a constant. This proves that bicarbonate ion $\left.\left(\mathrm{HCO}_{3}\right)^{-}\right)$at $10 \%$ and $20 \%(\%$ v) concentration, still be converted into biomass by the culture with the help of CA (Carbonic anhydrate), while the $30 \%$ and $40 \%(\% \mathrm{v})$ carbon dioxide concentration, CA began to saturate so that the effectiveness of CA, in the use of bicarbonate ion, begin to decrease.

\subsection{Effect of Nutrient}

Macro and micro nutrients are one of important factors that affecting the growth of microalgae. Macro nutrient consisting of $\mathrm{C}, \mathrm{H}, \mathrm{N}, \mathrm{P}, \mathrm{K}, \mathrm{S}, \mathrm{Mg}$ and $\mathrm{Ca}$, while the micro-nutrients such as $\mathrm{Fe}, \mathrm{Cu}, \mathrm{Mn}, \mathrm{Zn}, \mathrm{Co}, \mathrm{Mo}, \mathrm{Bo}$, $\mathrm{Vn}$ and $\mathrm{Si}$. The most important nutrient in the formation of biomass are $\mathrm{N}$ and $\mathrm{P}$ [8].

Table 1

The effect of adding nutrients against time of cultivation and the value of $\mu$.

\begin{tabular}{lcc}
\hline \multicolumn{1}{c}{ Parameter } & $\begin{array}{c}\text { Without nutrient } \\
\text { (Run 1) }\end{array}$ & $\begin{array}{c}\text { Addition of } \\
\text { nutrient (Run 4) }\end{array}$ \\
\hline $\begin{array}{l}\text { Cultivation time } \\
\mu / \text { day } \\
(\mathrm{Q}=0.071 \mathrm{~L} / \mathrm{min})\end{array}$ & 10 days & 7 days \\
$\begin{array}{l}\text { Biomass production } \\
\left(\mathrm{gr} / \mathrm{dm}^{3}\right)\end{array}$ & 0.16 & 0.33 \\
\hline
\end{tabular}

Table 1 shows that in Run 1, the time was required for microalgae cultivation (10 days) was longer than Run 4 which only takes 7 days. So that, the growth rate in Run 4 was greater than Run 1 . Microalgae obtains foods from the addition of nutrients to support their growth, thus shortening the time of cultivation.

\subsection{Effect of $p H$}

The higher cells density in the culture medium led to a slightly alkaline environment, thus causes the enhancement of carbon dioxide absorption in the culture medium [9]. Figure 4 shows that in Run 1 and Run 2, pH value in the culture medium more acidic due to insufficient nitrate. While in Run 3 and Run 4, the $\mathrm{pH}$ value in the culture medium became more alkaline because of adequate nitrate content (excess).

\subsection{Absorption of Carbon Dioxide}

Table 2 shows the ability of Chlamydomonas sp. to absorb carbon dioxide. In their growth phase, microalgae using water as its culture medium, the growth of microalgae is more easily observed than the higher plants. Microalgae can grow very quickly and does not require a large area to its growing media [10]. Carbon dioxide is an important compound that affects the rate of growth and metabolism of microalgae [5].

Table 2 shows the ability of microalgae to absorb carbon dioxide. The amount of carbon dioxide absorption reached $12.09 \%$, proportional to the addition of carbon dioxide concentration. This proved that carbon dioxide was used to increase the number of cells in culture medium. A large number of cells indicated an increase in biomass production.

Table 2

Absorption of carbon dioxide by microalgae at a flow rate $0071 \mathrm{~L}$ / $\min$

\begin{tabular}{cccc}
\hline $\begin{array}{c}\text { Carbon dioxide } \\
\text { concentration } \\
\text { (\% volume) }\end{array}$ & $\begin{array}{c}\text { Initial carbon } \\
\text { dioxide } \\
\mathbf{( \% )}\end{array}$ & $\begin{array}{c}\text { Final carbon } \\
\text { dioxide } \\
\mathbf{( \% )}\end{array}$ & $\begin{array}{c}\text { Carbon } \\
\text { dioxide was } \\
\text { absorbed } \\
\text { (\%) }\end{array}$ \\
\hline 10 & 8.82 & 5.79 & 3.03 \\
20 & 17.73 & 11.85 & 5.88 \\
30 & 29.76 & 20.61 & 9.15 \\
40 & 38.44 & 26.35 & 12.09 \\
\hline
\end{tabular}

\subsection{Effect of carbon dioxide on CCM / CA}

CCM (Carbon dioxide Concentrating Mechanism) is about CA (Carbonic anhydrase) that are present in intracellular or extracellular. CA used to convert carbonate compounds into biomass through photosynthetic process. At a certain point, the carbon dioxide, in the culture medium, will be saturated so it will turn into carbonate compounds if reacted to water. This carbonate compounds will be converted into biomass with the support of CA.

Figure 4 showed an enhancement in biomass production was directly proportional to the addition of carbon dioxide concentration. This indicated that CA was still effective (not saturated) so that the concentration of carbon dioxide could be improved.

\section{Conclusion}

The higher of carbon dioxide flow rate causes the growth rate and biomass productivity increases, during the optimal residence time of carbon dioxide. This indicates that the carbon dioxide absorbed by the culture medium can be utilized.

The high concentration of carbon dioxide led to increase biomass production. Although the concentration of carbon dioxide was already saturated, but the biomass production process was still ongoing, as long as CA was still effective / not saturated so that carbon dioxide could be converted into carbonate 
compounds. This compound could be transformed into biomas. pH and nutrient availability affect the growth of medium culture. An adequate nitrate and alkaline condition would enhance the growth of culture. The avaibility of light and carbon dioxide were very important factor for photosynthesis procesess.

\section{References}

[1] Balat M, Balat H (2009) Biogas as a Renewable Energy Source A Review. Energy Sour Part A Recovery Util Environ Eff 31: 1280-1293.

[2] Abatzoglou N, Boivin S (2009) A Review of Biogas Purification Processes. Biofuels Bioprod Biorefining 3: 42-71.

[3] Kapdi SS, Vijay VK, Rajesh SK, Prasad R (2005) Biogas Scrubbing, Compression and Storage: Perspective and Prospectus in Indian Context. Renew Energy 30: 1195-1202.

[4] Ajhar M., Travesset M, Yuce S, Melin T (2010) Siloxane Removal from Landfill and Digester Gas - A Technology Overview. Bioresour Technol 101: 2913-2923.

[5] Cho KS, Ryu HW, Lee NY (2000) Biological Deodorization of Hydrogen Sulphide using Porous Lava as a Carrier of Thiobacillus thiooxidans. J Biosci Bioeng 90: 25-31.

[6] Chung YC, Ho KL, Tseng CP (2003) Hydrogen Sulphide Gas Treatment by a Chemical-Biological Process: Chemical Absorption and Biological Oxidation Steps. J Environ Sci Health Part B-Pestic Contam Agric Wastes 38: 663-679.

[7] Chung YC, Ho KL, Tseng CP (2006) Treatment of high $\mathrm{H}_{2} \mathrm{~S}$ Concentrations by Chemical Absorption and Biological Oxidation Process. Environ Eng Sci 26: 942-53.

[8] Porpatham E, Ramesh A, Nagalingam B (2007) Effect of Hydrogen Addition on The Performance of a Biogas Fuelled Spark Ignition Engine. Int J Hydrogen Energy 32: 2057-2065.

[9] Favre E, Bounaceur R, Roizard D (2009) Biogas, Membranes and Carbon Dioxide Capture. J Membr Sci 238: 11-4.

[10] Holm-Nielsen JB, Al Seadi T, Oleskowicz-Popiel P (2009) The Future of Anaerobic Digestion and Biogas Utilization. Bioresour Technol 100: 5478-5484.
[11] Ho SH, Chen CY, Lee DJ, Chang, JS (2011) Perspectives on Microalgal $\mathrm{CO}_{2}$ Emission Mitigation System - A Review. Biotechnol Adv 29: 189-198.

[12] Wang B, Li Y, Wu N, Lan CQ (2008) $\mathrm{CO}_{2}$ Bio-Mitigation using Microalgae. Appl Microbiol Biotechnol 79: 707-718

[13] Demirbas A (2011) Biodiesel from Oligae, Biofixation of Carbon Dioxide by Microalgae: A Solution to Pollution Problems. Appl Energy 88: 3541-3547.

[14] Yoo C, Jun SY, Lee JY, Ahn CY, Oh HM (2010) Selection of Microalgae for Lipid Production under High Levels Carbon Dioxide. Bioresour Technol 101: 571-574.

[15] Brune DE, Lundquist TJ, Benemann JR (2009) Microalgal Biomass for Greenhouse Gas Reductions: Potential for Replacement of Fossil Fuels and Animal Feeds. J Environ EngASCE 135: 1136-1144.

[16] Li FF, Yang ZH, Zeng R, Yang G, Chang X, Yan JB (2011) Microalgae Capture of $\mathrm{CO}_{2}$ from Actual Flue Gas Discharged from A Combustion Chamber. Ind Eng Chem Res 50: 64966502.

[17] Chiu SY, Kao CY, Huang TT, Lin CJ, Ong SC, Chen CD (2011) Microalgal Biomass Production and On-Site Bioremediation of Carbon Dioxide, Nitrogen Oxide and Sulfur Dioxide from Flue Gas using Chlorella sp. Cultures. Bioresour Technol, 102: 91359142.

[18] Mata TM, Matins AA, Caetano NS (2010) Microalgae for Biodiesel Production and Other Applications: A Review. Renew Sust Energy Rev 14: 217-232.

[19] Chisti Y (2007) Biodiesel from Microalgae. Biotechnol Adv 25: 294-306.

[20] Li Y, Horsman M, Wu N, Lan QC, Dubois-Calero N (2008) Biofuels from microalgae. Biotechnol Progr 24: 815-820.

[21] Brennan L, Owende P (2010) Biofuels from Microagale - A Review of Technologies for Production, Processing, and Extractions of Biofuels and Co-Products. Renew Sust Energ Rev, 14: 557-577.

[22] Lee JY, Yoo C, Jun SY, Ahn, CY, Oh HM (2010) Comparison of Several Methods for Effective Lipid Extraction from Microalgae. Bioresour Technol 101: 575-577.

[23] Chen CY, Yeh KL, Aisyah R, Lee DJ, Chang JS (2011) Cultivation, Photobioreactor Design and Harvesting of Microalgae for Biodiesel Production: A Critical Review. Bioresour Technol 102: 71-81. 